\title{
Contribution of Morphological Variables in Garlic Bulb Yield
}

\author{
Job Teixeira de Oliveira, Rubens Alves de Oliveira, \\ Fernando França da Cunha, Isabela da Silva Ribeiro, \\ and Lucas Allan Almeida Oliveira \\ Federal University of Viçosa, Viçosa, 8560-090, Brazil
}

\author{
Paulo Eduardo Teodoro \\ Universidade Federal de Mato Grosso do Sul, Chapadão do Sul, 75560-000, \\ Brazil
}

Additional index words. path analysis, precision irrigation, Allium sativum

\begin{abstract}
The objective of this work was to investigate the direct and indirect relationships of morphological variables on garlic bulb yield. The primary components of garlic bulb yield, including clove mass, number of cloves per bulb, and bulb diameter and bulb length, are the variables that affect garlic bulb yield directly. Leaf length and growth of a secondary bulb had a negative correlation to garlic bulb yield. Growth of a secondary bulb also had a negative correlation with the number of cloves per bulb and root dry mass. Irrigation with the deficit, applied at the stage of bulb formation, had a positive correlation with garlic yield and a slightly negative correlation with total plant mass, bulb length, and secondary bulb growth.
\end{abstract}

Garlic is a horticultural crop consumed worldwide for its flavor and nutraceutical properties. Annual global garlic production in 2015 and 2016 was 26 to 27 million tons grown on $\approx 1.5$ million ha in several countries with different climates (Faostat, 2018). Water is the factor that most often affects the development, yield, and quality of garlic. Soil water deficiency mainly compromises plant development and bulb yield, whereas excess impairs quality and conservation (Costa et al., 1993). Because garlic is cultivated preferably in the cold season, coinciding with the driest season of the year, in the main producing regions, irrigation is a mandatory practice to meet the water needs of the crop and to ensure high yield.

The objective of garlic production is a high yield and high-quality bulbs. Obtaining such a culture is the result of many growth and development processes. Wellestablished principles determine the yield of a crop, which are demonstrated by several factors, such as quantity of leaves for greater light absorption, dry matter that can be harvested and produced, the proportion of irrigation applied and transferred to the fraction harvested from the plant, and so on.

Determining correlations among variables is a widely used technique to establish

Received for publication 10 Mar. 2020. Accepted for publication 3 Apr. 2020.

Published online 6 May 2020.

This study was financed in part by the Coordination for the Improvement of Higher Education Personnel, Brazil (CAPES); Finance Code 001.

P.E.T. is the corresponding author. E-mail: eduteodoro@hotmail.com.

This is an open access article distributed under the CC BY-NC-ND license (https://creativecommons. org/licenses/by-nc-nd/4.0/). how to increase yield in most crops. However, the correlation between two variables can be influenced by a third variable or a group of variables. Path analysis is the most appropriate technique to remove the effect of these other variables. It allows fractionating the correlation coefficient between two variables in direct and indirect effects. The variables with cause-and-effects relationships must have a high correlation with the main dependent variable, high direct effect and in the same sense of correlation, besides being easier to measure (Cruz et al., 2012).

Therefore, our objective was to investigate the relationship between morphological variables and garlic bulb yield, aiming to indicate criteria for direct selection, and to study the effects of irrigation with a deficit applied at the stage of bulb formation.

\section{Materials and Methods}

The study was developed in the area of irrigation and drainage of the Federal University of Viçosa, in Viçosa, Minas Gerais, Brazil, near the geographic coordinates $23 \mathrm{~K}$, $722569.09 \mathrm{~m} \mathrm{E} ; 7701897.59 \mathrm{~m} \mathrm{~S}$ (UTM). According to Köppen classification, the climate is classified as Cwa (humid subtropical climate with dry winters), and $20.6{ }^{\circ} \mathrm{C}$ is the average temperature in Viçosa. The summer has much more rainfall than the winter, and the average annual rainfall is $1229 \mathrm{~mm}$.

In the field of crop management, with a conventional planting system in an irrigated area, the soil was plowed and harrowed, and then raised beds were made with the aid of a rotating hoe for the planting of garlic. The field soil was prepared on 1 May 2018; on 7 May 2018, the planting of a purple garlic cultivar was carried out. Each sampling point was constituted by a site measuring $1.60 \mathrm{~m}$ in width and $1.60 \mathrm{~m}$ in length (total area, $2.56 \mathrm{~m}^{2}$ ), with three double rows of garlic. A useful area comprised the middle row, and the lateral rows and $0.30 \mathrm{~m}$ of each edge were disregarded. The spacing between the double rows was $0.40 \mathrm{~m}$ and $0.10 \mathrm{~m}$ between the rows of the double row (Marouelli et al., 2014).

The $x$ and $y$ directions of the cartesian coordinate system were defined and, at the end of the garlic phenological cycle (around 15 Sept. 2018), the experimental grid was staked in plots spaced at $1.6 \mathrm{~m}$ between them. Each experimental grid constituted three transects of $48 \times 1.6 \mathrm{~m}$. Therefore, the transects were spaced at $1.6 \mathrm{~m}$, with sample points squared in $1.6 \times 1.6 \mathrm{~m}$, containing 90 of them. The production components were determined individually in the useful area of the sampling point, which was a double row with a $1.0-\mathrm{m}$ length and included 20 plants.

The variables evaluated were garlic bulb yield, total plant mass, floral tassel length, leaf length, leaf width, number of leaves, shoot dry mass, pseudostem diameter, number of cloves per bulb, clove mass, root dry mass, bulb diameter, bulb length, secondary bulb growth, and, an external component interference, irrigation with deficit applied at bulb formation.

Initially, Pearson's correlations between variables were estimated. Afterward, the diagnosis of multicollinearity was performed according to Montgomery et al. (2012). Finally, the trial analysis was performed considering yield (YIE) as the main dependent variable. All statistical analyses were performed using the software GENES (Cruz, 2013).

\section{Results and Discussion}

There was a high positive correlation between garlic bulb diameter and clove mass. Also, these variables showed high correlation with garlic bulb yield. Similar results were obtained in other studies with garlic. Castellanos et al. (2004) and Babaleshwar et al. (2017) studied the correlation between garlic bulb yield, clove size, and bulb diameter, and found high positive correlations between the same variables.

According to the condition number criterion presented by Montgomery et al. (2012), the Pearson correlation estimation matrix obtained here presented strong multicollinearity (condition number $=789$ ). Thus, in the presence of multicollinearity, all the variables evaluated in the path analysis can be included, but a constant $(k=0.05)$ must be added to the diagonal of the correlation matrix to solve this problem. This constant caused the determinant of the correlation matrix to be nonzero (Cruz et al., 2012).

In our work, the presentation of the results was made through a scheme where it is possible to verify that the variables that had the greatest direct effect on garlic bulb yield were clove mass, number of cloves per bulb, and bulb diameter and length (Fig. 1). Considering that a variable is feasible for direct selection of more productive plants, it needs to have a direct effect and high correlation in the same direction as garlic bulb yield. In this way, the variables of bulb diameter and clove 


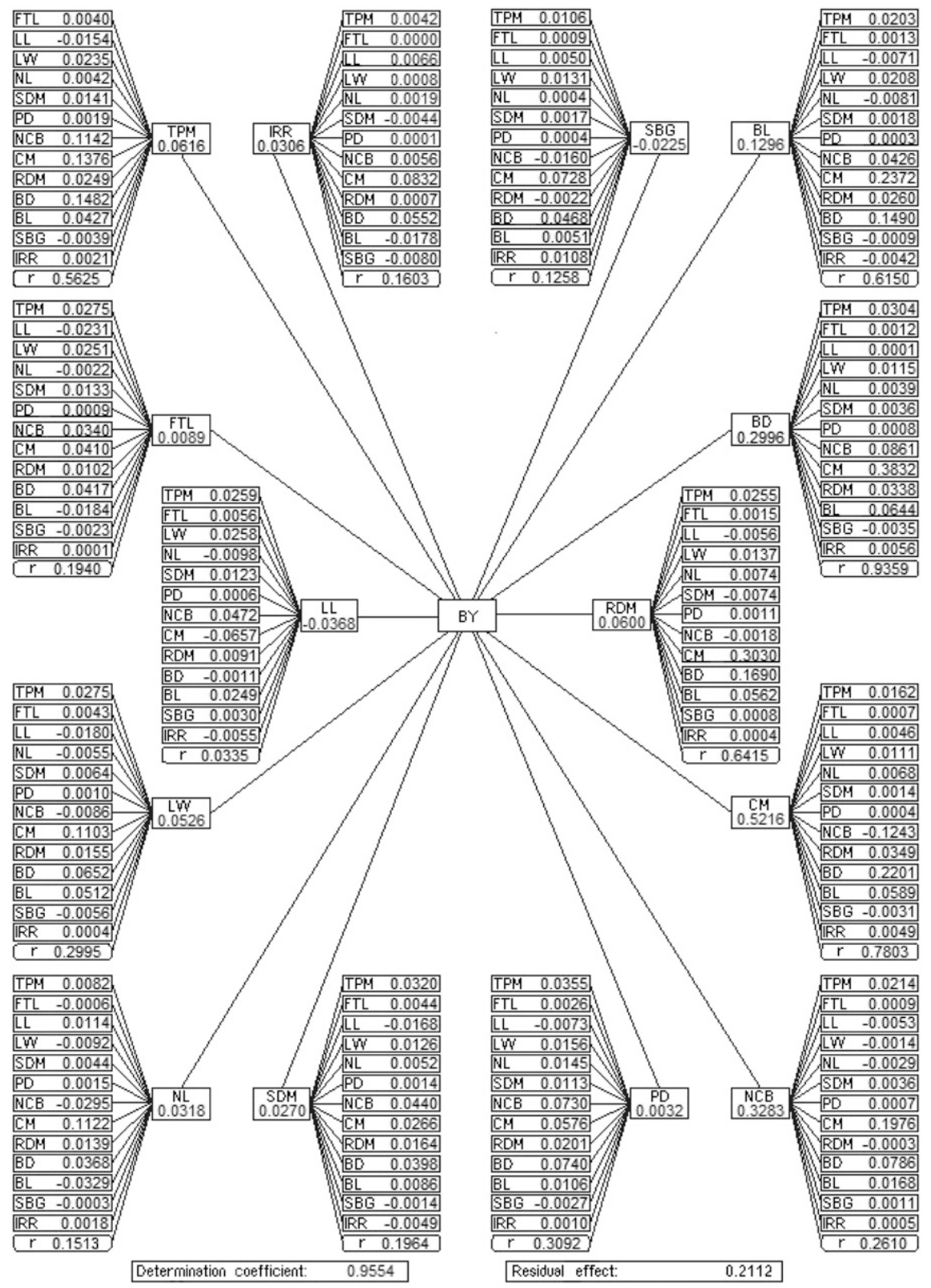

Fig. 1. Path analysis between morphological variables and garlic bulb yield (BY), with its primary components.

mass are the most suitable for direct selection of the most productive garlic, because they have a cause-and-effect relationship with crop yield.

In our study, a high coefficient of determination (0.9554) was obtained. In turn can be implemented to improve and enhance this important crop of vegetables through better studies of irrigation management with consequent conservation of natural resources. This result suggests that the variables evaluated explain most of the YIE (main dependent variable).

\section{Conclusions}

Our analyses made it possible to verify that among the primary components of garlic bulb yield, clove mass, number of cloves per bulb, and bulb diameter and length are phe- nological indices of the greatest potential for selection and identification of garlic bulb yield.

Irrigation at a deficit, applied at the stage of bulb formation, showed a slightly negative correlation with total plant mass, bulb length, and secondary bulb growth.

\section{Literature Cited}

Babaleshwar, S.B., S.R. Koppad, K.K. Math, and R. Dharmatti. 2017. Influence of sulphur on growth and yield of garlic (Allium sativum L.). J. Pharm. Phytochem. 6(5):450-452.

Castellanos, J.Z., P. Vargas-Tapia, J.L. Ojodeagua, G. Hoyos, G. Alcantar-Gonzalez, F.S. Méndez, and A.A. Gardea. 2004. Garlic productivity and profitability as affected by seed clove size, planting density and planting method. HortScience 39:1272-1277.
Costa, T.M.P., R.J. Souza, and A.M. Silva. 1993. Efeitos de diferentes lâminas de água e doses de nitrogênio sobre a cultura do alho (Allium sativum L). Cien. Prat. 17(3):239-246.

Cruz, C.D. 2013. Genes: A software package for analysis in experimental statistics and quantitative genetics. Acta Sci. Agron. 35:271-276.

Cruz, C.D., P.C.S. Carneiro, and A.J. Regazzi. 2012. Modelos biométricos aplicados ao melhoramento genético. 3rd ed. Editora UFV, Viçosa, Brazil.

Faostat. 2018. Statistics database. $<$ http://www.fao.org/ faostat/en/\#home>.

Marouelli, W.A., M.B. Braga, M.A. Lucini, and F.V. Resende. 2014. Irrigação na cultura do alho. Ministério da Agricultura, Pecuária e Abastecimento, Embrapa, Brasília, Brazil.

Montgomery, D.C., E.A. Peck, and G.G . Vining. 2012. Introduction to linear regression analysis. 5th ed. Wiley, New York, NY. 